\title{
Physiological Indices and Nutritive Values of the Sea Urchin Paracentrotus lividus (Lamarck, 1816) (Echinodermata Echi- noidea) of the Algerian West Coast
}

\author{
Mediani Lynda*, Chahrour Faycal, Dermeche Saliha \& Bouderbala Mohamed
}

Laboratoire Réseau de Surveillance Environnementale (LRSE), Département de Biologie, Faculté des Sciences de la Nature et de la Vie, Université Oran1 Ahmed Ben Bella Oran, Algeria

${ }^{*}$ Corresponding author, e-mail: lyndamediani_27@hotmail.com

\begin{abstract}
Seasonal variation in the physiological indices and biochemical composition of the sea urchin Paracentrotus lividus (Lamarck, 1816) (Echinodermata Echinoidea) from the west coast of Algeria were studied between March 2016 and February 2017 from three stations of different nature and geographical position: Sidi Lakhdar (S1), Cap Carbon (S2), and Benisaf harbor (S3). Two spawning period occurred in spring and autumn, resulting in a fall in gonad indices to a low level with values between 2.14 and $3.65 \%$. The seawater temperature in the three sampling stations revealed that the latter had a spawning rate at $9-15^{\circ} \mathrm{C}$ in spring and 24 and $11^{\circ} \mathrm{C}$ in autumn corresponding to the two peaks of spawning. The biochemical composition of the gonads protein contents, carbohydrates and lipids were recorded with a high percentage for proteins between (25.80 and 45.23\%) followed by that of lipids (9.21 and $14.40 \%)$ and finally carbohydrates (3.49 and 7.39\%). In accordance with the gonad cycle, sea urchin lipids and proteins show a marked seasonal variation with a decrease in their percentages during the spawning period. Protein levels had an inverse profile with carbohydrates, with their values at a minimum when carbohydrates were at their maximum. The profile of the total components in the gut content is almost the same as in the gonads with minus values. A relationship has been found between the biochemical components of the gonads and the digestive tract during gametogenesis, the latter seems to be an organ that tends to store nutrients, indicating that populations of sea urchin P. lividus are in good nutritional conditions.
\end{abstract}

KEY WORDS Mediterranean Sea; Biochemical composition; Physiological indices; Sea urchin.

Received 11.09.2019; accepted 18.02.2020; published online 06.03.2020

\section{INTRODUCTION}

The reproductive cycle of the sea urchin Paracentrotus lividus (Lamarck, 1816) (Echinodermata Echinoidea) has been extensively studied in Ireland (Byrne, 1990), in Brittany (Allain, 1972; Spirlet et al., 1998), in the Canary Islands (Girard et al., 2006), in Morocco (Bayed et al., 2005), in Algeria (Dermeche et al., 2009; Dermeche et al., 2012;
Boukhelf 2012; Belkhedim, 2010, 2015; Belkhedim, 2010, 2015 et al., 2014), and across the Mediterranean Sea (Fenaux, 1968; Lozano et al., 1995; Guettaf, 1997; Sánchez-España et al., 2004).

Several studies have been carried out on biochemical composition of sea urchin gonads in different parts of the world in order to evaluate and improve the important nutrients for these species (Keats et al., 1984; Fernandez, 1998; Montero-Tor- 
reiro \& Garcia Martinez, 2003, Epherra, 2010; Arafa, 2012).

Studies on the biochemical composition and nutritional value in Algeria are non-existent despite the global economic importance of this echinid due to its gonads as seafood, hence the interest of the study by the strategy of the reproduction of $P$. lividus through the monitoring of gonad index and repletion index (GI, RI) in relation to the variations in the biochemical composition of the gonads and gut of sea urchins in different substrate media and floristic components to detect possible adaptations or changes in the behavior of this species as a result of changes in environmental conditions that may significantly affect the physiology of the sea urchin.

\section{MATERIAL AND METHODS}

\section{Study area}

The study area extends along the west coast of Algeria (Figure 1). Three sampling stations were selected by contribution to their characteristics: the first site, Sidi Lakhdar (S1), being under the influence of the watershed of wadi seddaoua North East of Mostaganem wilaya $\left(36^{\circ} 12^{\prime} 40,63^{\prime \prime} \mathrm{N}-0^{\circ} 23^{\prime}\right.$ $20,78^{\prime \prime} \mathrm{E}$ ), a zone characterized by a soft substrate and rich in photophilic algae and by the presence of the sparse beds of the Posidonia oceanica phanerogam, (Dermeche et al., 2010; Boukhelf, 2012); the second site, Cap Carbon (S2), located at

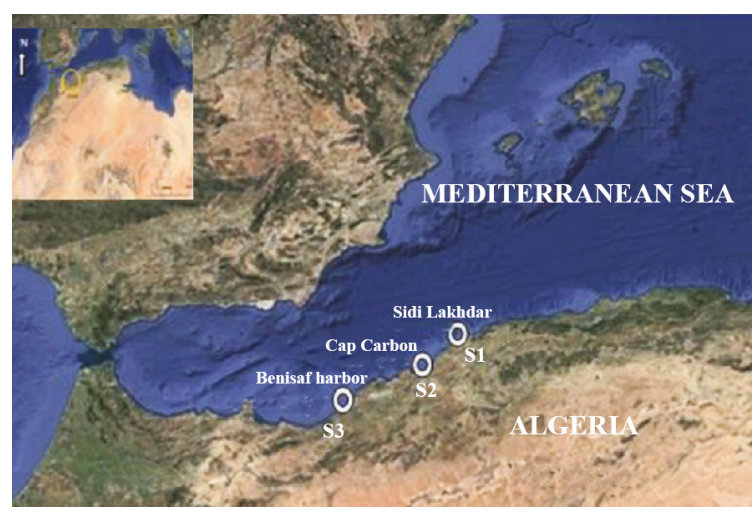

Figure 1. Geographical location of the sampling stations on the western coast of Algeria: Sidi Lakhdar (S1), Cap Carbon (S2), and Benisaf harbor (S3). the Arzew golf (35'54'05.71'”N - 0²0’20.98”W), characterized by a rocky habitat rich in macrophyte (Kouadri, 2014; Boudjella, 2015); the third site, Benisaf harbor (S3), (35'18'16.8'N - 1'23'37.9'W) is characterized by a rocky substrate rich in photophilic algae and also by the presence of organic matter (Benguedda-rahal, 2011-12).

\section{Samples collection}

The study was conducted from March 2016 to February 2017 . Sea urchins ( $\approx 20$ specimens) per station with a diameter ranging between 45 and 60 $\mathrm{mm}$ were monthly collected from the intertidal zone at 0.5 meters up to 2 meters deep. The temperature was measured on the surface of the sea. Each sea urchin is opened by cutting the oral cap, the gonads and the gut were previously extracted, drained and weighed for the study of physiological indices, then frozen at $-80{ }^{\circ} \mathrm{C}$ for a biochemical analysis.

Physiological indices. The individual total wet weight (TWW) was measured before dissection, gonad weight (GW) and gut content weight (GCW) were measured for each organism to the nearest $0.01 \mathrm{~g}$ for physiological index determination.

Repletion index (RI) and gonad index (GI) were calculated for each individual using the following equations: $\mathrm{RI}=(\mathrm{GCW} / \mathrm{TWW}) \times 100$ and $\mathrm{GI}=$ $(\mathrm{GW} / \mathrm{TWW}) \times 100$ (Fenaux et al.,1977; Carboni et al., 2015).

Biochemical analysis. For proteins, the method of Lowry et al. (1951) was applied after extraction in phosphate buffer using bovine serum albumin (BSA) as the standard. For carbohydrate, the sample was assayed according to the method of Dubois et al. (1956) using glucose as a standard. Total lipids were extracted and quantified according to the method of (Folch et al., 1957).

\section{Statistical analyzes}

Results are presented as the means \pm standard deviations (mean \pm SD). Homogeneity of the data was explored with the Levene test, a post hoc multiple comparison analysis of Duncan was chosen to determine the differences between the independent factors.

For better interpretation, the data were analyzed by Pearson correlation. All statistical analyses were 
performed with the use of the software package Statistica 6.0 and SPSS 20 .

\section{RESULTS}

The average monthly gonad index (GI) and repletion index (RI) as a function of seawater temperature are shown in figure 2.

Evolution monitoring of the physiological index at the three stations shows a significant average monthly variation (Anova $\mathrm{F}=3.41$ ) $\mathrm{p}<0.001$. The highest values of the RI in order of $18.88 \pm$ $2.14 \%$ (May) is registered at site 1 and $15.87 \pm$ $2.84 \%$ (May) at site 2 and $16.52 \pm 1.49 \%$ (April), at site 3, against minimum values used for all individuals recorded one month before spawning in order of $7.28 \pm 3.51 \%$ (September), $6.64 \pm 2.21 \%$ (March), and $7.25 \pm 1.84 \%$ (February) for the three sites respectively. In terms of gonadal index, average percentages were significantly affected by season (Anova $\mathrm{F}=3.90$ ) $\mathrm{p}<0.05$, the highest values being observed in September at the S1 with 11.67 $\pm 1.42 \%$ and in January at both site 2 and site 3 with values of $9.31 \pm 1.74 \%$ and $9.47 \pm 0.68 \%$ respectively. While the lowest values translate into a sharp drop in the percentage of GI, being from $2.14 \pm$ $1.33 \%$ (March) and $3.18 \pm 1.29 \%$ (November) at site $1,(3.4 \pm 0.68 \%)$ in April and $(2.26 \pm 0.76 \%)$ in September at site 2, and for populations at site 3, values are recorded at April $(2.19 \pm 1.22 \%)$ and October $(3.65 \pm 1.31 \%)$.

The monthly sampling of the seawater temperature among the three study stations reveals its importance in the physiology of reproduction, hence the values between $9{ }^{\circ} \mathrm{C}$ and $24^{\circ} \mathrm{C}$ favored the development of the different populations of individuals by the action of gamete spawning. We note that our results reveal that this abiotic factor has an importance on the spawning phenomenon which is recorded for a temperature between $9{ }^{\circ} \mathrm{C}$ and $15^{\circ} \mathrm{C}$ for spring and $24{ }^{\circ} \mathrm{C}$ to $11^{\circ} \mathrm{C}$ for autumn, which is confronted by the values of IGm which fall during these two seasons (Fig. 2).

Variance analysis of the biochemical composition of the gonads and the gut of different populations of $P$. lividus reveal that the interaction of factors (site, season, organ) significantly affects the protein contents $(\mathrm{F}=1.80)$, carbohydrates $(\mathrm{F}=$ 1.76) and lipids $(\mathrm{F}=2.63) \mathrm{p}<0.05$.
The gonadal protein content at the first site $(\mathrm{S} 1)$ is significantly elevated $(\mathrm{p}<0.05)$ in winter $(45.23$ $\pm 2.54 \% \mathrm{WW})$ compared to spring $(26,73 \pm 6,33 \%$ WW $)$ and autumn $(30.81 \pm 3.34 \% \mathrm{WW})$, however no difference was recorded in summer (37.76 \pm $3.34 \% \mathrm{WW}$ ).

For lipids, their percentage in spring $(9.58 \pm 0.94 \% \mathrm{WW})$ and autumn $(10.12 \pm 3.97 \%$ WW) are significantly lower by contribution to summer $(14.25 \pm 1,55 \% \mathrm{WW})$ and winter $(14.40 \pm$ $1.39 \% \mathrm{WW})$. Concerning percentages of carbohydrate, summer $(3.72 \pm 0.96 \% \mathrm{WW})$ and winter $(4.10 \pm 0.56 \% \mathrm{WW})$ are significantly lower compared to spring $(7.21 \pm 0.59 \% \mathrm{WW})$ and autumn $(6.83 \pm 0.56 \% \mathrm{WW})$.

At the Cap Carbon site (S2), there is a significant difference in protein percentage where values are low in spring $(23.88 \pm 5.62 \% \mathrm{PF})$ and autumn $(26.81 \pm 4.37 \% \mathrm{WW})$ compared with winter (39.79 $\pm 4.58 \% \mathrm{WW}$ ) whereas the latter did not show any difference with summer $(36.56 \pm 3.37 \% \mathrm{WW})$. For lipids, the summer season $(13.89 \pm 1.09 \% \mathrm{WW})$ recorded a significantly high difference compared with the spring season $(9.52 \pm 2.44 \% \mathrm{WW})$ and autumn season $(9.65 \pm 0.56 \% \mathrm{WW})$, but no difference with the winter season $(13.19 \pm 0.66 \% \mathrm{ww})$. As for carbohydrates, their percentage is significantly low in summer $(3.83 \pm 1.26 \% \mathrm{WW})$ compared to spring $(6.79 \pm 1.60 \% \mathrm{WW})$ and autumn $(7.35 \pm 1.89 \%$ $\mathrm{WW})$, however no difference was recorded in winter $(4.38 \pm 1.74 \%$ WW $)(\mathrm{p}<0.05)$.

About the Benisaf (S3), the protein percentages are significantly high in the summer season (41.80 $\pm 5.04 \% \mathrm{WW})$ and winter season (43.30 \pm $2.98 \% \mathrm{WW})$ compared to the spring season $(26.21$ $\pm 2.59 \% \mathrm{WW})$ and autumn season $(27.56 \pm 2.84 \%$ WW).

For lipids, the summer season $(14.06 \pm 1.28 \%$ WW) is significantly elevated by contribution to the spring season $(9.25 \pm 1.08 \% \mathrm{WW})$, however no significance has been obtained with the autumn season $(10.13 \pm 0.75 \% \mathrm{WW})$ and winter season (13.12 \pm $0.66 \% \mathrm{WW})$. About carbohydrates, the summer season is significantly low $(3.49 \pm 0.52 \% \mathrm{WW})$ compared to other seasons (Fig. 3).

Concerning the gut, no significant difference was recorded by contributing to the seasonal variation in biochemical components at S1 and S2. Regarding the $\mathrm{S} 3$, the percentages of proteins are significantly lower in winter $(23.24 \pm 6.33 \% \mathrm{WW})$ 
compared with spring $(36.33 \pm 5.06 \% \mathrm{WW})$, however no difference is recorded in summer $(27.58 \pm$ $5.74 \% \mathrm{WW})$ and autumn $(32.77 \pm 3.04 \% \mathrm{WW})$ (Fig. 4).

For clarity in our results, using the Pearson correlation revealed a significant difference between the percentages of the repletion index and carbohydrates $(r s=0.45)$ and is very significant with the percentages of proteins $(\mathrm{rs}=0.85)$ and lipids $(\mathrm{rs}=$ $0.85)$ at $\mathrm{S} 1$.

The same, significant difference is recorded between the percentages of the repletion index and the carbohydrates $(\mathrm{rs}=0.45)$, and very significant with the percentages of the proteins $(\mathrm{rs}=0.85)$ and lipids $(\mathrm{rs}=0.79)$. For the $\mathrm{S} 2$, the explanation is that the percentages, the repletion index and the biochemical components grow in the same direction, but this increase is not significant.

The annual variance analysis of the biochemical composition of the gonads and gut conten of the edible sea urchin P. lividus populations revealed no significant differences between the three study stations.

\section{DISCUSSION}

The fluctuations of the physiological index (GI, RI) make it possible to follow the gonadic activity according to the approach of the trophic evolution of this Echinid.

The evolution of GI fluctuates from one season to another with a decrease in spring and autumn for the three populations of sea urchins indicating the presence of a double spawning within the populations of $P$. lividus frequenting different stations of the West Algerian coastal fringe. These results obtained are consistent with those of the Spanish and North Mediterranean populations (Guettaf, 1997; Guettaf et al., 2000; Sanchez-España et al., 2004; Sellem \& Guillou, 2007; Dermeche et al., 2010; Belkhedim, 2015; Sartori et al., 2015).

Sea urchins tend to have a period of accumulation of nutritive reserve, before each laying, this will allow to store these reserves and to use them during the phase of gametic maturity or there will be consumption of biochemical components stored in the gonads as source of energy (Byrne, 1990; Lozano et al., 1995), from which this phenomenon is seen at its peak in winter and summer.
Fluctuations in RI reveal that during its elevation this would indicate a supply of energy for a gametic maturity, the more the sea urchin feeds, the more it develops its gonads (Lawrence et al., 1989). In Echinoidea, the feeding rate is low when the gonads are highly developed (Lawrence, 1975, 1987; Sellem 1990; Lumingas 1994; Lozano et al., 1995). According to Leighton (1968), the development of the gonads causes a physical decrease in the space of the coelomic cavity, therefore the space available is insufficient for the gut and its content, resulting in a fall of the repletion index (Fig. 5).

However, Lawrence \& Lane (1982) suggested that variations in the intestinal index reflected the amount of food consumed. In Arbacia lixula, variations in gonadal and intestinal indices were positively correlated and the gonads were not voluminous, so the gut would have a coelomic space for its development (Tavares, 2004).

Edible sea urchin populations are under the influence of the abiotic parameters of the surrounding environment (Fenaux, 1968) and the measurement of the seawater temperature at the three sampling stations revealed that the latter induce spawning between 9 and $15^{\circ} \mathrm{C}$ in spring and 24 and $11^{\circ} \mathrm{C}$ in autumn.

The temperature of seawater in the natural environment of $P$. lividus varies from $18{ }^{\circ} \mathrm{C}$ to $25^{\circ} \mathrm{C}$ (Boudouresque \& Verlaque, 2007). Le Gall et al. (1990) reported that somatic growth of P. lividus was enhanced at temperatures ranging from $18{ }^{\circ} \mathrm{C}$ to 20 ${ }^{\circ} \mathrm{C}$. Fernandez (1996) achieved the best results with the same temperatures. Shpigel et al. (2004) reported that temperature fluctuations between $18-22^{\circ} \mathrm{C}$ improve both gonad growth and development, while by increasing temperature to $24^{\circ} \mathrm{C}$, growth slows.

According to Régis (1979) and Byrne (1990), the fall in temperature during the coldest and the shortest months of the year triggers the growth of the gonads of the Mediterranean and Irish populations, whereas Spirlet et al. (1998) reports that the increase in seawater temperature in spring triggers gametogenesis. Thus, temperature is a factor influencing the reproductive modalities of $P$. lividus populations (Fenaux, 1968).

Another factor that has been found to be very important in the gonadal development process is the availability of food, which allows them increased access to food (Byrne, 1990), and other factors such as the quality of the biotope, phytoplankton bloom, 


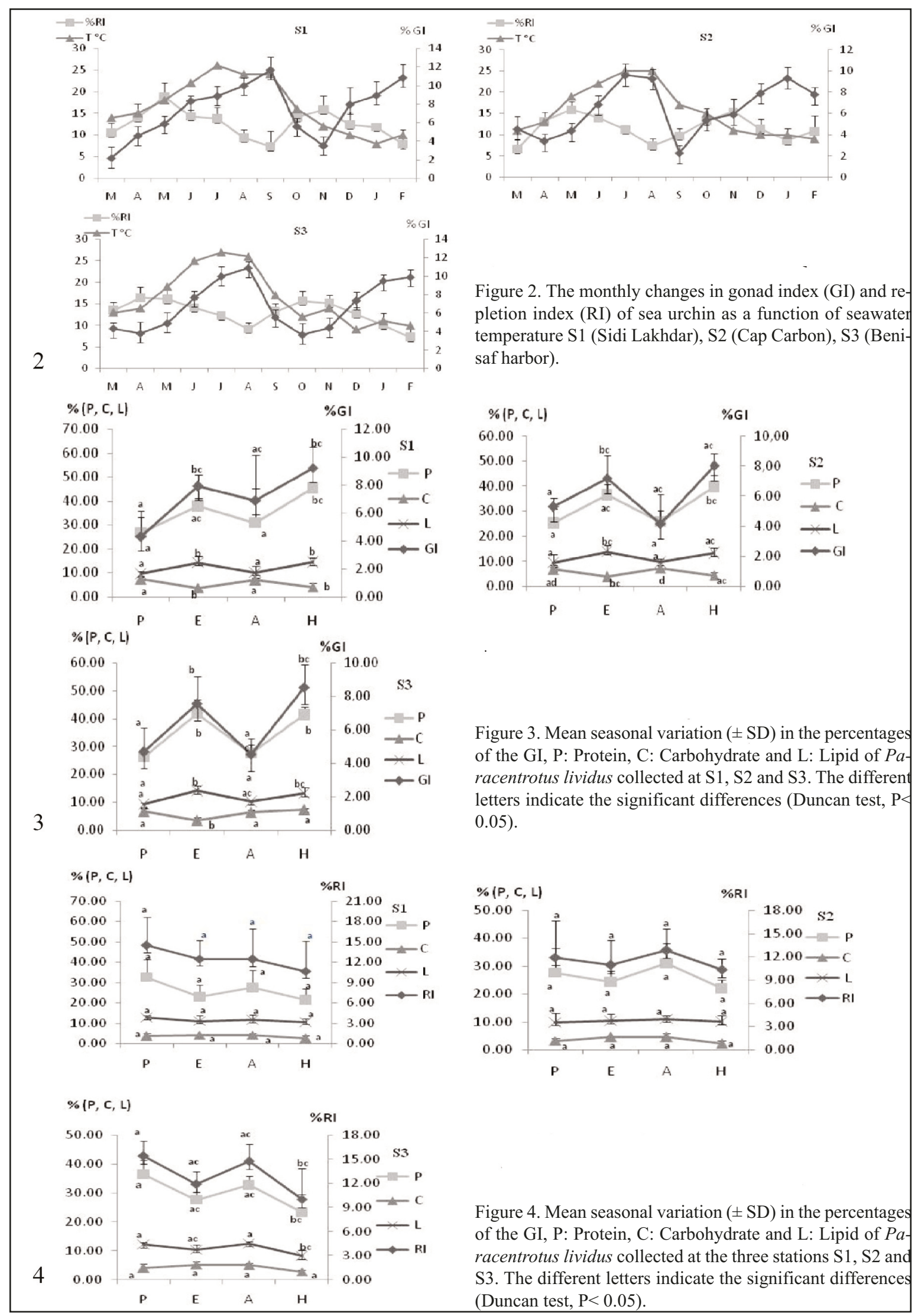




\begin{tabular}{|c|c|c|c|c|c|c|c|}
\hline \multirow[t]{2}{*}{ Site } & \multirow[t]{2}{*}{ Organ } & \multicolumn{3}{|c|}{ Gonad } & \multicolumn{3}{|c|}{ Gut } \\
\hline & & $\% \mathrm{P}$ & $\% \mathrm{C}$ & $\% \mathrm{~L}$ & $\% \mathrm{P}$ & $\% \mathrm{C}$ & $\% \mathrm{~L}$ \\
\hline \multirow[t]{4}{*}{ S1 } & $\mathrm{P}$ & $26.73 \pm 6.34$ & $7.21 \pm 1.17$ & $9.58 \pm 0.94$ & $32.52 \pm 8.64$ & $3.74 \pm 1.25$ & $12.74 \pm 1.06$ \\
\hline & $\mathrm{E}$ & $37.76 \pm 3.34$ & $3.72 \pm 0.96$ & $14.25 \pm 1.47$ & $23.04 \pm 5.76$ & $4.23 \pm 0.19$ & $11.07 \pm 2.67$ \\
\hline & A & $30.81 \pm 14.4$ & $6.83 \pm 2.07$ & $10.12 \pm 4.01$ & $27.35 \pm 8.68$ & $4.17 \pm 1.00$ & $11.51 \pm 2.55$ \\
\hline & $\mathrm{H}$ & $45.23 \pm 2.54$ & $4.13 \pm 0.86$ & $14.40 \pm 1.40$ & $21.43 \pm 5.45$ & $2.46 \pm 1.54$ & $10.42 \pm 1.74$ \\
\hline \multirow[t]{4}{*}{ S2 } & $\mathrm{P}$ & $25.22 \pm 5.62$ & $6.79 \pm 1.61$ & $9.52 \pm 2.45$ & $27.61 \pm 8.74$ & $3.17 \pm 0.85$ & $9.67 \pm 3.38$ \\
\hline & E & $36.56 \pm 4.12$ & $3.83 \pm 1.26$ & $13.89 \pm 1.09$ & $24.33 \pm 3.94$ & $4.39 \pm 0.61$ & $10.23+2.57$ \\
\hline & A & $25.80 \pm 4.37$ & $7.32 \pm 1.43$ & $9.65 \pm 0.56$ & $30.93 \pm 7.22$ & $4.46 \pm 1.25$ & $10.98 \pm 1.40$ \\
\hline & $\mathrm{H}$ & $39.79 \pm 4.58$ & $4.38 \pm 1.74$ & $13.19 \pm 0.66$ & $21.91 \pm 3.06$ & $2.12 \pm 1.05$ & $10.08 \pm 2.15$ \\
\hline \multirow[t]{4}{*}{ S3 } & $\mathrm{P}$ & $26.21 \pm 2.59$ & $6.60 \pm 1.58$ & $9.21 \pm 1.09$ & $36.33 \pm 5.07$ & $4.06 \pm 1.34$ & $12.16 \pm 0.7$ \\
\hline & E & $41.80 \pm 5.04$ & $3.49 \pm 0.52$ & $14.06 \pm 1.28$ & $27.58 \pm 5.74$ & $5.22 \pm 1.15$ & $10.35 \pm 1.83$ \\
\hline & A & $27.56 \pm 2.84$ & $6.37 \pm 1.39$ & $10.13 \pm 0.75$ & $32.77 \pm 3.04$ & $5.12 \pm 0.71$ & $12.44 \pm 0.61$ \\
\hline & $\mathrm{H}$ & $41.30 \pm 2.97$ & $7.39 \pm 0.63$ & $13.12 \pm 0.66$ & $23.24 \pm 6.34$ & $2.87 \pm 0.53$ & $8.17 \pm 2.09$ \\
\hline
\end{tabular}

Table 1. Percentage of seasonal soft tissue biochemical components of sea urchin populations at the three study stations S1 (Sidi Lakhdar), S2 (Cap Carbon), S3 (Benisaf harbor).

photoperiodism, depth and hormones will also influence this physiological process (Himmelman, 1986; Pearse et al., 1988). Not only the accumulation of nutrients by the nutritive phagocytes, but also the accumulation of gametes contribute to gonad growth and weight.

The growth of the gonads, mainly depends on the type of food available, in quantity and quality, as well as the organic matter ingested. According to Regis (1979) and Rico (1989), invertebrates can apparently use as an energetic resource organic matter dissolved in water by absorbing it with their quills (sestenophagy).

In Table 2, the different percentage values of proteins, carbohydrates and lipids are indicated. According to our results, protein is the main component of the gonads and gut followed by lipids and finally carbohydrates with lower proportions.

Such results in the distribution of biochemical components are similar in all echinid species, which vary with the seasons (McClintock et al., 1987; Lawrence et al, 1989; Rowley, 1990; Frantzis \& Grémare, 1993; Fernandez, 1996; Fernandez, 1998), quality and quantity of food intake (Cook et al., 1998; Montero-Torreiro \& Garcia-Martinez, 2003), temperature variations (Spirlet et al., 1998) and the reproductive cycle (Fenaux et al., 1977; Fernandez, 1998).

The results of the biochemical components obtained in P. lividus are close to those of other echi- noids, as the case with Arbacia lixula (Fenaux et al., 1975, 1977) and P. lividus in a lagoon environment (Fernandez, 1996).

Protein levels in the gonadal tissues show significant variations over the study period, corresponding to the highest level with the highest values of the GI, which would be an indication of the protein requirements in gonads during gametogenesis period.

Proteins are considered to be the main nutrientrich food nutrient involved in reproduction, leading to increased somatic and gonadal growth rates, the latter due to the accumulation of gametes or nutrients (Fernandez \& Boudouresque, 1997, 2000; Cook \& Kelly, 2007). Gonad weight growth is mainly associated with the ingestion of nutrients, the quantity and quality of food ingested (Lawrence \& Lane 1982; Cuesta - Gomez \& Sánchez-Saavedra, 2014).

The profile of the total proteins in the digestive content is practically the same as in the gonads, unlike other works, in which the levels have remained practically constant. These facts could be explained by the importance of the diet in the biochemical composition of the digestive content, as well as, by the inverse relationship observed in P. lividus between the intake and absorption rates of the food, when conditions are more favorable for the development of algae, coincide with the phase of gametogenesis. 


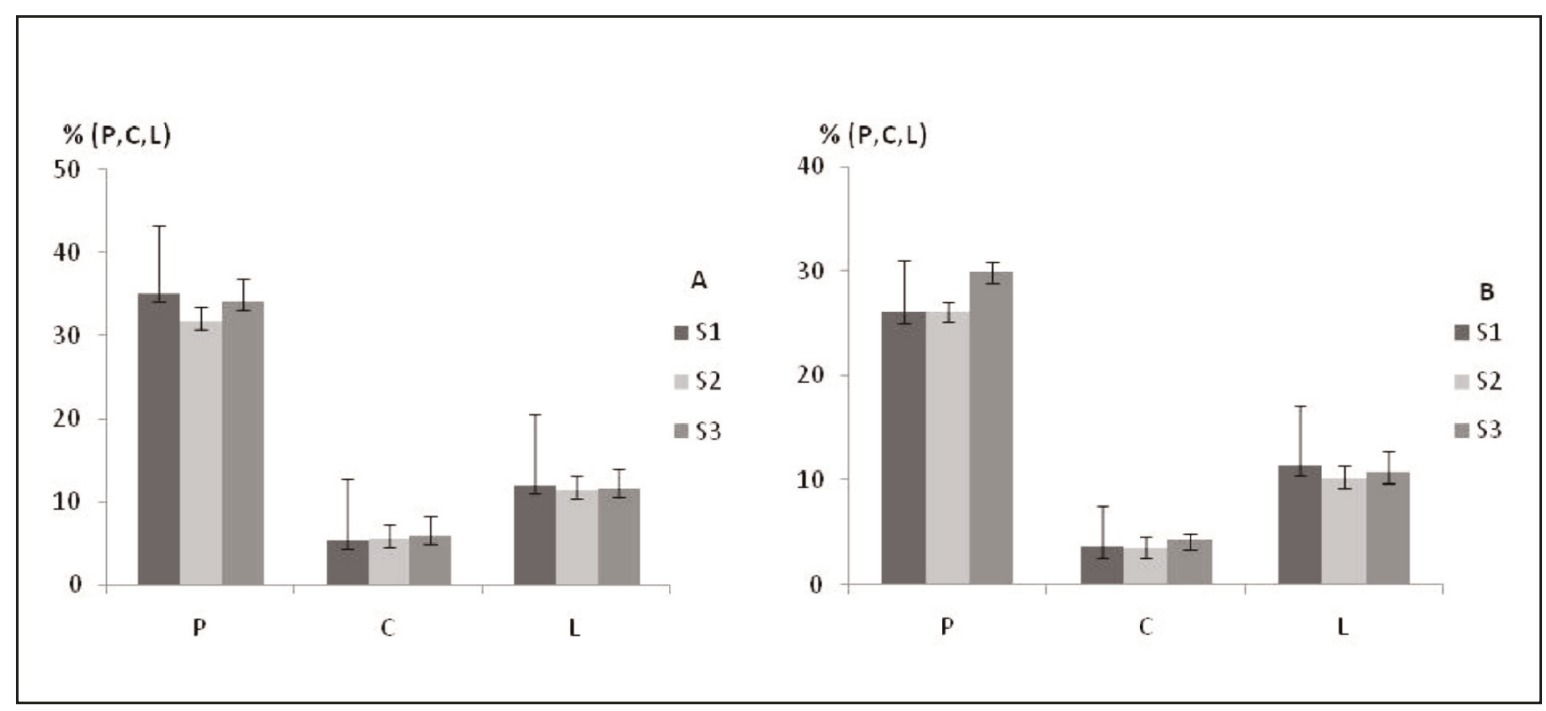

Figure 4. Comparative inter-site study of variation in percentages of biochemical components measured at the $\mathrm{n}$ of the gonads (A) and gut content (B). S1 (Sidi Lakhdar), S2 (Cap Carbon), S3 (Benisaf harbor). P: Protein; C: Carbohydrate; L: Lipid.

The maximum protein percentages of the gut content will appear because of the high consumption of macrophyte, but this Echinidae could not absorb such a quantity of proteins, because of the rare musculature associated with $P$. lividus, so the proteins would be retained in the digestive system (Frantzis \& Grémare, 1992).

Before initiating gametic development, sea urchin gonads accumulate nutrients in nutrient phagocytes for later use (Walker et al., 2001). In order to carry out gametogenesis, Jangoux \& van Impe (1977) observed a decrease in the amount of protein in the $A s$ terias rubens Linnaeus, 1758 (Echinodermata Asteroidea), when the gonadal demand in structural material, in the form of amino acids, was high. Gametogenesis requires so much energy that sea urchins prepare for this event, both nutritionally and physiologically (Ferguson, 1975).

As for carbohydrate levels in the gut, they are lower than those of gonadal tissue, a fact that has already been proven in other species of echinids. However, in another study conducted by Fernandez (1998), in P. lividus, carbohydrate values in the gut found similar to those of gonadal tissue, which were justified by the role of the digestive tract as an organ reserve.

In contrast, in the gonads, where carbohydrates are required as the primary source of energy during oogenesis, it presents some extra high levels in spring and autumn, according to the theory that glu- cose is the first source of energy to be used during the gonadal period of development (Ansel, 1974). Patrick et al. (2006) has demonstrated the inverse relationship between gonadal mass and carbohydrate levels in the oyster Magallana gigas (Thunberg, 1793) (Mollusca Bivalvia).

It should be noted that there is an inverse relationship between glucose content and total protein in P. lividus gonads, which seems to be a clear indication of the use of carbohydrate stores to obtain the energy needed to the synthesis of proteins, which is fundamental in the formation of gametes (Fenaux et al., 1977). Similar situations have been observed in Strongylocentrotus purpuratus (Giese, 1966), Abatus shackletoni (McClintock \& Pearse, 1987), Arbacia lixula (Fenaux et al., 1977; Tavares, 2004), Echinometera lucunter (Linnaeus, 1758) (Tavares, 2004). ) and P. lividus (Fernández, 1998, Montero-Torreiro \& Garcia-Martinez, 2003) (see also Table 2).

Total lipids in P. lividus are affected by the season, lipids suggest nutrient accumulation during gonadal development, values dropped significantly during spawning, which would indicate that deposits observed towards the end of gametogenesis would correspond to storage in gametes. Psammechinus miliaris (P.L.S. Müller, 1771) (Echinoidea Parechinidae) showed differences in lipid composition before spawning, whereas the composition was paired after this event, indicating that 
these components were deposited in the gametes during the last stage of gametogenesis (Hughes et al., 2006).

The total lipids in the digestive tract, unlike the gonadal, do not have a seasonal variation profile. Therefore, it seems clear the direct relationship between total lipids in the gut and the bioavailability of favorable food for algal production, which is the basis of the diet of P. lividus. The same conclusion, had already been exposed by Oudejans \& van der Sluis (1979), who established that one of the main causes of variation in total lipid levels in the pyloric caeca of the starfish, Asterias rubens is the ability of the organ to digest and to accumulate the lipids contained in food.

During periods of gametogenesis, a positive correlation was found between gonadal lipid percentages and gut in sea urchin populations at S1 (R2 = $0.62), \mathrm{S} 2(\mathrm{R} 2=0.76)$ and S3 $(\mathrm{R} 2=0.93)$. For proteins, only S2 and S3 were positively correlated with $(\mathrm{R} 2=0.96)$ and $(\mathrm{R} 2=0.95)$ respectively. Concerning carbohydrate, a positive correlation was recorded at $\mathrm{S} 1$ with $(\mathrm{R} 2=0.94)$ and $\mathrm{S} 2(\mathrm{R} 2=0.69)$.

It has been possible to demonstrate through our results, a transfer of the components, from the gut to the gonads in the populations of sea urchins $P$. lividus, and their use as a source for the biosynthesis of the gametic tissues, which confirms that the gonads and the digestive system are probably dependent organs from the point of view of nutritive and energetic needs in order to properly conduct gametogenesis.

\section{CONCLUSIONS}

The evolution of the GI fluctuates monthly with a decrease in spring and autumn, indicating the presence of a double spawning within the different $P$. lividus populations frequenting the west Algerian coastal fringe. The biochemical cycle is directly related to the reproductive cycle, with a higher proportion of proteins, followed by lipids and carbohydrates. The quality of the gonads has been affected by their biochemical composition that change according to their reproductive stages, from the storage of nutrients in the somatic cells provided by the gut to an increase in the number and / or size of gonadal cells.

In $P$. lividus, energy requirements during gametogenesis would be provided by food intake and nutrient transfer observed from intestines to gonads.

\begin{tabular}{|c|c|c|c|c|c|}
\hline Species & Organ & $\% \mathrm{P}$ & $\% \mathrm{C}$ & $\% \mathrm{~L}$ & References \\
\hline \multirow{2}{*}{$\begin{array}{l}\text { Strongylocentrotus } \\
\text { purpuratus } \\
\text { (Stimpson, 1857) }\end{array}$} & $\begin{array}{c}\mathrm{G} \\
\text { Int }\end{array}$ & $\begin{array}{c}32-41 \\
41.0-49.0\end{array}$ & $\begin{array}{c}3.3-7 \\
18.0-20.0\end{array}$ & $\begin{array}{l}21-27 \\
3.1-4.6\end{array}$ & Lawrence et al., 1966 \\
\hline & $\begin{array}{l}\mathrm{G} \\
\text { Int }\end{array}$ & $\begin{array}{l}24.0-36.9 \\
28.3-41.7\end{array}$ & $\begin{array}{l}2.0-7.3 \\
3.10\end{array}$ & $\begin{array}{l}14.2-27.9 \\
20.3-30.0\end{array}$ & Giese, 1966 \\
\hline $\begin{array}{l}\text { Abatus shackletoni } \\
\text { Koehler, 1911 }\end{array}$ & $\begin{array}{c}\mathrm{G} \\
\text { Int }\end{array}$ & $\begin{array}{l}56.2 \\
34.5 \\
\end{array}$ & $\begin{array}{l}4.6 \\
1.6 \\
\end{array}$ & $\begin{array}{c}27.0 \\
3.7 \\
\end{array}$ & McClintock et Pearse, 1987 \\
\hline \multirow[t]{2}{*}{$\begin{array}{l}\text { Arbacia lixula } \\
\text { (Linnaeus, 1758) }\end{array}$} & $\begin{array}{c}\mathrm{G} \\
\text { Int }\end{array}$ & $\begin{array}{l}38.1 \\
48.2\end{array}$ & $\begin{array}{l}5.2 \\
5.8\end{array}$ & $\begin{array}{l}15.7 \\
18.8\end{array}$ & Fenaux et al.,1975 \\
\hline & $\begin{array}{l}\mathrm{G} \\
\text { Int }\end{array}$ & $\begin{array}{ll}30.2 & -51.5 \\
29.9 & -40.5 \\
\end{array}$ & $\begin{array}{l}4.2-7.0 \\
3.4-10.2 \\
\end{array}$ & $\begin{array}{l}9.8-15.5 \\
13.4-18 \\
\end{array}$ & Fenaux et al.,1977 \\
\hline \multirow[t]{4}{*}{$\begin{array}{l}\text { Paracentrotus lividus } \\
\text { (Lamarck, } 1816\end{array}$} & $\begin{array}{c}\mathrm{G} \\
\text { Int }\end{array}$ & $\begin{array}{l}39.1 \\
38.1 \\
\end{array}$ & $\begin{array}{c}9.7 \\
20.1 \\
\end{array}$ & $\begin{array}{c}15.6 \\
8.8 \\
\end{array}$ & Fernandez, 1996 \\
\hline & $\begin{array}{c}\mathrm{G} \\
\text { Int }\end{array}$ & $\begin{array}{l}30-40 \\
33-45 \\
\end{array}$ & $\begin{array}{c}5.15 \\
3.4-12.6 \\
\end{array}$ & $\begin{array}{c}12-18 \\
10.6-27.2\end{array}$ & Fernandez, 1998 \\
\hline & $\begin{array}{c}\mathrm{G} \\
\text { Int }\end{array}$ & $\begin{array}{c}36-6024.1 \\
-42.0 \\
\end{array}$ & $\begin{array}{l}7.1-14.0 \\
28.6-31.1 \\
\end{array}$ & $\begin{array}{c}12.8-16.1 \\
6.4-9.9\end{array}$ & Montero Torreiro et al., 1998 \\
\hline & $\begin{array}{c}\mathrm{G} \\
\text { Int }\end{array}$ & $\begin{array}{l}25.8-45.2 \\
21.9-34.6\end{array}$ & $\begin{array}{l}3.4-7.0 \\
2.1-4.9\end{array}$ & $\begin{array}{l}9.2-14.4 \\
9.6-12.7\end{array}$ & present study \\
\hline
\end{tabular}

Table 2. Comparative table of the biochemical composition of the gonads and intestines expressed as a percentage: Protein (P), Carbohydrate (C) and Lipid (L) in different Echinid Species. G: Gonads, Int: Intestine. 
This further confirms that echinoid gonads behave as an organ that tends to provide two functions: gamete production and energy storage.

Variations in the availability and quality of food in different habitats did not significantly affect the physiology of sea urchin populations, which is possible due to the high phenotypic plasticity of adaptation of $P$. lividus to the environment, conditions and way of life as well as a decrease in metabolic demand and / or a decrease in growth when individuals are important in their size, so the need for food is less important, while the reproductive power is maintained (Fernandez, 1996). Confirmed by some echinoids that feed at a low rate and the gonads are fully developed, similarly, a positive correlation is found between the gonadal and repletion index and this did not affect the development of the sea urchin as the gonads were not voluminous.

\section{REFERENCES}

Allain J.-Y., 1972. Structure des populations de Paracentrotus lividus (Lamark) (Echinodermata, Echinoidea) soumises à la pêche sur les côtes du nord de Bretagne. Revue et Travaux de l'Institut des Pêches Maritimes, 39: 171-212.

Ansell A.D., 1974. Seasonal changes in biochemical composition of the bivalve Abra alba from the Clyde sea area. Marine Biology, 25: 13-20.

Arafa S., Chouaibi M., Sadok S. \& El Abed A., 2012. The influence of season on the gonad index and biochemical composition of the sea urchin Paracentrotus lividus from the Golf of Tunis. The Scientific World Journal, 1-8. https://doi.org/10.1100/2012/815935

Bayed A., Quiniou F., Benhra A. \& Guillou M., 2005. The Paracentrotus lividus populations from the Northern Moroccan Atlantic Coast: Growth, reproduction and heath condition. Journal of the Marine Biological Association of the United Kingdom, 85: 999-1007.

Belkhedim L., 2015. Étude de la reproduction et de la contamination métallique chez l'oursin comestible Paracentrotus lividus (Lmch, 1816) du Méditerrané sud occidental (Algérie). Thèse Doctorat, Université d'Oran, 210 pp.

Belkhedim L., 2010. Contribution à l'étude de la biologie de l'oursin régulier Paracentrotus lividus (Lmck, 1816) du Port d'Oran et d'Ain Franine. Thèse de Magistère, LRSE, Biologie et Pollution Marines Université d'Oran, 99 pp + Annexes.

Belkhedim L., Dermeche S., Chahrour F. \& Boutiba Z., 2014. Physiological Indices and Reproduction in the
Sea urchin Paracentrotus lividus (Lamarck, 1816) Echinodermata Echinoidea in the west coast of Algeria. Ijrras, 18: 173-181.

Boudjella I., 2015. Dosage des compose phénoliques chez Posidonia oceanica (Linné, 1813) Delille des herbiers de la cote ouest algérienne (Ain Franine, Cap Carbon et Sidilakhder). Thèse de Magistère, Université d'Oran, 174 pp.

Boudouresque C.F. \& Verlaque M., 2007. Ecology of Paracentrotus lividus. In: Lawrence J.M. (Ed.), Edible sea urchins: biology and ecology, 2nd edition, Elsevier. Developments in Aquaculture and Fisheries Science 37: 243-285.

Boukhelf., 2012, Données biométriques, indices physiologiques et dosage des métaux lourds chez l'oursin comestible Paracentrotus lividus (Lamarck, 1816) dans la région de Mostaganem (Algérie). Thèse de Magistère, LRSE, Biologie et Pollution Marines Université d'Oran, $150 \mathrm{pp}+$ Annexes

Byrne, 1990. Annual reproductive cycles of the commercial sea-urchin Paracentrotus lividus from an exposed intertidal and a sheltered subtidal habitat on the west coast of island. Marine Biology, 104: 275289.

Carboni S., Hughes A.D., Atack T., Tocher D.R. \& Migaud H., 2015. Influence of broodstock diet on somatic growth, fecundity, gonad carotenoids and larval survival of sea urchin. Aquaculture Research, 46: 969-976. https://doi.org/10.1111/are.12256

Cook E.J. \& Kelly M.S., 2007. Enhanced production of the sea urchin Paracentrotus lividus in integrated open-water cultivation with Atlantic salmon Salmo salar. Aquaculture, 273: 573-585. https://doi.org/10. 1016/j.aquaculture.2007.10.038

Cook E.J., Kelly M.S. \& McKenzie J.D., 1998. Somatic and gonadal growth of the sea urchin Psammechinus miliaris (Gmelin) fed artificial salmon feed compared with a macro algal diet. Journal of Shellfish Research, 17: 1549-1555.

Cuesta-Gomez D.M. \& Sánchez-Saavedra M., 2014. Increased gonad growth of the purple sea urchin (Strongylocentrotus purpuratus) fed the giant kelp (Macrocystis pyrifera) and the sea lettuce (Ulva lactuca) enriched with nutrients. Aquaculture Research, 47: 2150-2163. https://doi.org/10.1111/are.12669

Dermeche S., Chahrour F. \& Boutiba Z., 2012. Evaluation of the toxicity of metal pollutants on embryonic development of the sea urchin Paracentrotus lividus (Lamarck, 1816) (Echinodermata Echinoidea). Biodiversity Journal, 3: 165-172.

Dermeche S., Chahrour F. \& Boutiba Z., 2010. Indices physiologiques, Métaux lourds $(\mathrm{Cd}, \mathrm{Pb}, \mathrm{Cu}, \mathrm{Zn}$ et $\mathrm{Ni})$ et bioessais chez l'oursin commun Paracentrotus lividus (Lamarck, 1816) pêché dans le golfe d'Arzew et d'Oran. Thèse Université d'Oran, 212 pp. 
Dermeche S., Chahrour F. \& Boutiba Z., 2006. Contribution à l'étude des variations des Indices physiologiques (indice de réplétion-indice gonadique et sex-ratio) chez la copulation d'oursins comestibles Paracentrotus lividus (Lamarck 1816) du littoral occidental algérien. European Journal of Scientific Research, 30: 153-163.

Dubois M., Gilles K.A., Hamilton J.K., Rebers P.A. \& Smith F., 1956. Colorimetric method for determination of sugars and related substances. Analytical Chemistry, 28: 350-356.

Epherra L., 2010. Ciclo bioquímico del erizo verde $A r$ bacia dufresnii (Blainville, 1825), en costas del Golfo Nuevo, Patagonia. Seminario de Licenciatura, 39 pp.

Fenaux L., 1968. Maturation des gonades et cycles saisonniers des larves chez A. lixula, Paracentrotus lividus et Psammechinus microtuberculatus (Echinides). Vie Milieu, 19: 1-52.

Fenaux L., Malara G. \& Charra R., 1975. Effets d'un jeûne de courte durée sur les principaux constituants biochimiques de l'oursin Arbacia lixula. I. Stade de repos sexuel. Marine Biology, 30: 239-244.

Fenaux et al., 1977. Evolution des constituants biochimiques des principaux compartiments de l'oursin $\mathrm{Ar}$ bacia lixula (L.) au cours d'un cycle sexuel et effets d'un jeune de courte durée au cours de la maturation sexuelle. Journal of Experimental Marine Biology and Ecology, 28: 17-30.

Ferguson J.C., 1975. Fatty acid and carbohydrate storage in the annual reproductive cycle of Echinaster. Comparative Biochemistry and Physiology, 52: 585-590.

Fernandez C., 1996. Croissance et nutrition de l'oursin Paracentrotus lividus dans le cadre d'un projet aquacole avec alimentation artificielle.Thèse de Doctorat en Océanologie Université de Corse, France, 200 pp.

Fernandez C., 1997. Effect of diet on the biochemical composition of Paracentrotus lividus (Echinodermata: Echinoidea) under natural and rearing conditions (effect of diet on biochemical composition of urchins). Comparative Biochemistry and Physiology Part A: Physiology, 118: 1377-1384.

Fernandez C., 1998. Seasonal changes in the biochemical composition of the edible sea urchin Paracentrotus lividus (Echinodermata: Echinoidea) in a Lagoonal Environment. Marine Ecology, 19: 1-11.

Fernández C. \& Boudouresque C.F., 1997. Phenotypic plasticity of Paracentrotus lividus (Echinodermata: Echinoidea) in a lagoonal environment. Marine Ecology Progress Series, 152: 145-154.

Fernandez C. \& Boudouresque C.F., 2000. Nutrition of the sea urchin Paracentrotus lividus (Echinodermata: Echinoidea) fed different artificial food. Marine Ecology Progress Series, 204: 131-141.

Folch J., Lees M. \& Sloane-Stanley G.H.,1957. A simple method for the isolation and purification of total lipi- des from animal tissues. The Journal of Biological Chemistry, 226: 497-509.

Frantzis A. \& Grémare A., 1992. Ingestion, absorption, and growth rates of Paracentrotus lividus (Echinodermata: Echinoidea) fed different macrophytes. Marine Ecology Progress Series, 95: 169-183.

Frantzis A. \& Grémare A., 1993. Ingestion, absorption, and growth rates of Paracentrotus lividus (Echinodermata: Echinoidea) fed different macrophytes. Marine Ecology Progress Series, 95: 169-183. https:// doi.org/10.3354/meps095169

Giese A.C., 1966. On the Biochemical Constitution of some echinoderm. In: Boolootian R.A. (Ed.), Physiology of Echinodermata. Interscience, New York, pp. 757-796.

Girard D., Hernandez J.C., Toledo K., Clemente S. \& Brito A., 2006. Aproximacion a la biologia reproductiva del equinoideo Paracentrotus lividus (Lamarck, 1816) en el litoral de Tenerife. Libro de Resúmenes, XIV SIEBM.

Guettaf M., 1997. Contribution à l'étude de la variabilité $\mathrm{du}$ cycle reproductif (indice gonadique et histologie des gonades) chez Paracentrotus lividus (Echinodermata: Echinoidea) en Méditerranée Sud Occidentale (Algérie). Thèse de Doctorat en Océanologie Université d'Aix-Marseille II, France, 132 pp.

Guettaf M., San Martin G.A. \& Francour P., 2000. Interpopulation variability of the reproductive cycle of Paracentrotus lividus (Echinodermata: Echinoidea) in the south-western Mediterranean. Journal of the Marine Biological Association of the UK, 80: 899907. https://doi.org/10.1017/S0025315400002885

Himmelman J.H., 1986. Population biology of green sea urchins on rocky barrens. Marine Ecology Progress Series, 33: 295-306.

Hughes A.D., Kelly M.S., Barnes D.K.A., Catarino A.I. $\&$ Black K.D., 2006. The dual functions of sea urchin gonads are reflected in the temporal variations of their biochemistry. Marine Biology, 148: 789-798. https:// doi.org/110.1007/s00227-005-0124-0.

Jacquin A.G., Donval A., Guillou J., Leyzour S., Deslandes E. \& Guillou M., 2006. The reproductive response of the sea urchins Paracentrotus lividus (G.) and Psammechinus miliaris (L.) to a hyperproteinated macrophytic diet. Journal of Experimental Marine Biology and Ecology, 339: 43-54.

James PJ. \& Heath PL., 2008. Long term gonads enhancement of Evechinus chloroticus. Aquaculture, 278: 89-96.

Jangoux M. \& van Impe E., 1977. The annual pyloric cycle of Asterias rubens L. (Echinodermata: Asteroidea). Journal of Experimental Marine Biology and Ecology, 30: 165-184.

Keats D.W., Steele D.H. \& South G.R., 1984. Depth-dependent reproductive out up of the green sea urchin, 
Strongylocentratus droebachiensis (O.F. Muller), in relation to the nature and aviability of food. Journal of Experimental Marine Biology and Ecology, 80: 77-91.

Kouadri M.F., 2014. Contribution a l'étude de la biologie de l'oursin comestible Paracentrotus lividus (Lamarck, 1816) de la cote occidentale algerienne (Cap carbon et Ain franine). Thèse de Magistère, LRSE, Biologie et Pollution Marines Université d'Oran, $107 \mathrm{pp}$.

Lasker R. \& Giese A.C., 1954. Nutrition of sea urchin Strongylocentrotus purpuratus. Biological Bulletin, 6: 328-340.

Lawrence J.M. \& Lane J.M., 1982. The utilization of nutrients by post-metamorphic echinoderms. In: Jangoux M. \& Lawrence J.M. (Eds.), Echinoderm nutrition. Balkema, Rotterdam, pp. 331-371.

Lawrence J.M.,1975. On the relationships between marine plants and sea-urchins. Oceanography and Marine Biology, 13: 213-286.

Lawrence J.M., 1987. A functional biology of Echinoderms. In: Calow P. (Ed.), Functional Biology Series. Croom Helm, London, pp. 332-340.

Lawrence J., Régis M.-B., Delmas P., Gras G. \& Klinger T., 1989. The effect of quality of food on feeding and digestion in Paracentrotus lividus (Lamarck) (Echinodermata: Echinoidea). Marine \& Freshwater Behaviour \& Physiology, 15: 137-144. https://doi.org/10. 1080/10236248909378724

Le Gall P., 1990. Culture of Echinoderms. In: Barnabé G (Eds.),Aquaculture, Vol. 1. Ellis Horwood Press 1990, New York, USA, pp. 443-462.

Leighton D.P., 1968. A comparative study of food selection and nutritio in the abalone Haliotis rufescens (Swainson) and the sea urchin Strongylocentrotus purpuratus (Stimpson). Ph. D. Thesis University California, San Diego, 197 pp.

Lowry H.O., Rosebrough N.J., Farr A.L. \& Randall R.J., 1951. Protein measurement with the Folin fenol reagent. Journal of Biological Chemistry, 193: 265275.

Lozano J., Galera J., López S., Turon X., Palacín C. \& Morera G., 1995. Biological cycles and recruitment of Paracentrotus lividus (Echinodermata: Echinoidea) in two contrasting habitats. Marine Ecology Progress, 122: 179-191.

Lumingas L.J.L., 1994. La plasticite chez l'oursin: cas de Sphaerechinus granularis en rade de Brest (Bretagne, France). Universite de Bretagne Occidentale, Oceanologie Biologique, Brest, France, 171 pp.

McClintock J.B. \& Pearse J.S., 1987. Biochemical composition of Antarctic echinoderms. Comparative Biochemistry and Physiology, 86B: 683-687.

Montero Torreiro M.F., Garcia Martinez P., Catoira J.L. \& Mosquera G., 1998. Seasonal variation in bio- chemical composition in gonads of the sea urchin, Paracentrotus lividus LMK. en Moore and Telford, editores. Echinoderm Research. Balkema, Netherlands.

Montero-Torreiro M.F \& Garcia-Martinez P., 2003. Seasonal changes in the biochemical composition of body components of the sea urchin, Paracentrotus lividus, in Lorbe (Galicia, north-western Spain). Journal of the Marine Biological Association of the United Kingdom, 83: 575-581.

Nichols D., Bishop G.M. \& Sime A.A.T., 1985. Reproductive and nutritional periodicities in populations of the european sea-urchin, Echinus esculentus (Echinodermata: Echinoidea) from the English channel. Journal of the Marine Biological Association of the United Kingdom, 65: 203-220.

Oudejans R.C.H.M. \& van der Sluis I., 1979. Storage and depletion of lipid components in the pyloric caeca and ovaries of the seastar Asterias rubens during its annual reproductive cycle. Marine Biologie, 53: 239-247.

Patrick S., 2006. Changements saisonniers du métabolisme des glucides et sa relation avec la mortalité estivale de l'huître creuse du Pacifique Crassostrea gigas dans la baie de Marennes - Oléron (France) VL252.

Pearse J.S., Mc Clary D.J., Sewell M.A., Austin W.C., Perez-Ruzafa A. \& Byrne M., 1988. Simultaneous spawning of six species of echinoderms in Barkley Sound, British Columbia. Invertebrate Reproduction and Development, 14: 279-288.

Benguedda-Rahal W., 2011-12. Contribution à l'étude de la bioaccumulation métallique dans les sédiments et différents maillons de la chaine trophique du littoral extrême ouest algérien. Thèse Université de Tlemcen, Alger, 149 pp.

Regis M.B., 1979. Analyse des fluctuations des indices physiologiques chez Paracentrotus lividus (LmK) et Arbacia lixula (L) du golf de Marseille. Téthys, 9: 167-181.

Rico V., 1989. Contribution a l'étude des preferanda alimentaires et du comportement moteur de l'oursin regulier Paracentrotus lividus. Faculté des Sciences Université d'Aix-Marseille, France, 41 pp.

Rowley R.J.,1990. Newly settled sea urchins in a kelp bed and urchin barren ground: a comparison of growth and mortality. Marine Ecology Progress Series, 62: 229-240.

Sánchez-España A.I., Martínez-Pita I. \& García F.J., 2004. Gonadal growth and reproduction in the commercial sea urchin Paracentrotus lividus (Lamarck, 1816) (Echinodermata: Echinoidea) from southern Spain. Hydrobiologia, 519: 61-72. https://doi.org/ 10.1023/B:HYDR.0000026485.40173.02

Sartori D., Scuderi A., Sansone G. \& Gaion A., 2015. Echinoculture: the rearing of Paracentrotus lividus 
in a recirculating aquaculture system-experiments of artificial diets for the maintenance of sexual maturation. Aquaculture International, 23: 111-125.

Sellem F. \& Guillou M., 2007. Reproductive biology of Paracentrotus lividus (Echinodermata: Echinoidea) in two contrasting habitats of northern Tunisia (south-east mediterranean). Journal of the Marine Biological Association of the United Kingdom, 87: 763-767.

Sellem F., 1990. Données sur la biométrie de Paracentrotus lividus, Arbacia lixula et Sphaerechinus granularis et sur la biologie de Paracentrotus lividus dans le golfe de Tunisie. Rapp. D.E.A. Biologie Marine et Océanologie, Université Tunis II, Tunisia, 158 pp. + Annexes.

Shpigel M., McBride S.C., Marciano S. \& Lupatsch I.,
2004. The effect of photoperiod and temperature on the reproduction of European sea urchin Paracentrotus lividus. Aquaculture, 232: 343-355.

Spirlet C., Grosjean P. \& Jangoux M., 1998. Reproductive cycle of the echinoid Paracentrotus lividus. Analysis by means of the maturity index. Invertebrate Reproduction and Development, 34: 69-81.

Tavares Y.A.G., 2004. Biologia reprodutiva dos equinóides Echinometra lucunter (Linnaeus, 1758) e Arbacia lixula (Linnaeus, 1758) na Ilha da Galheta, litoral paranaense, Brasil. $\mathrm{PhD}$. Thesis Universidade Federal do Paraná, Brasil, 575 pp.

Walker C.W., Unuma T., McGinn N.A., Harrington F.E. \& Lesser M.P., 2001. Reproduction of sea urchins. In: Lawrence J.M. (Ed.), The Edible Sea Urchin, Elsevier, Amsterdam, pp. 5-26. 